\title{
Environmental Contaminants in Redheads Wintering in Coastal Louisiana and Texas
}

\author{
T. C. Michot ${ }^{1}$, T. W. Custer ${ }^{2}$, A. J. Nault ${ }^{1}$, C. A. Mitchell ${ }^{2 *}$ \\ ${ }^{1}$ National Biological Survey, National Wetlands Research Center, 700 Cajundome Boulevard, Lafayette, Louisiana 70506, USA \\ ${ }^{2}$ National Biological Survey, Patuxent Wildlife Research Center, P.O. Box 2618, LaCrosse, Wisconsin 54601, USA
}

Received: 13 December 1993

\begin{abstract}
Whole body and liver analyses indicated that wintering redheads (Aythya americana; $\mathrm{n}=70$ ) in coastal Louisiana (one site) and Texas (two sites) were relatively free of contamination with common trace elements, organochlorines, and hydrocarbons. Most trace elements, including $\mathrm{As}, \mathrm{Cr}, \mathrm{Hg}, \mathrm{Mg}$, $\mathrm{Mn}, \mathrm{Ni}, \mathrm{Pb}, \mathrm{Se}, \mathrm{Sr}$, and $\mathrm{Zn}$, were within background concentrations in livers; levels of $\mathrm{B}, \mathrm{Cd}, \mathrm{Cu}$, and $\mathrm{Fe}$ were elevated in some specimens. Only one organochlorine, DDE, was detected in redhead carcasses, but its concentration was below reported toxic levels in waterfowl. Body burdens of aliphatic and aromatic hydrocarbons were generally low, but levels of pristane, total hydrocarbons, and the ratios of phytane: $n$-octadecane and pristane: $n$-heptadecane were indicative of possible chronic exposure to petroleum. Based on brain cholinesterase assays, redheads were not recently exposed to organophosphorous or carbamate pesticides. Of 30 elements or compounds tested for seasonal differences, only Se increased from early to late winter at one of the three sites. Eight of 57 contaminants differed among the three sites; no sex or age differences were found.
\end{abstract}

Elevated levels of contaminants may affect waterfowl numbers by reducing survival or reproduction (Davison and Sell 1974; Risebrough and Anderson 1975; Ohlendorf et al. 1986). Contaminant studies in waterfowl from wild populations in North America have been conducted primarily in freshwater ecosystems (Smith et al. 1985; Fleming and O'Shea 1980; Benson et al. 1976), whereas studies in estuarine systems have been limited (Ohlendorf et al. 1986; DiGiulio 1982).

The Laguna Madre and adjacent bays along the Texas coast support the highest numbers of wintering redheads (about 300,000 birds) in North America (Bellrose 1980). Chandeleur Sound, Louisiana, is also an important wintering area and sup-

*Present address: National Biological Survey, Northern Prairie Wildlife Research Center, P.O. Box 2226, LaCrosse, WI 54601 ports about 20,000 redheads (Bellrose 1980). As part of a larger study on the ecology of redheads in Louisiana and Texas, we investigated contaminant burdens in redheads collected from two sites in the Laguna Madre region of Texas and from one site in the Chandeleur Sound, Louisiana (Figure 1).

The objectives were to determine concentrations of various trace elements, organochlorines (OCs), and petroleum hydrocarbons (HCs) in redheads from three sites; to determine whether those levels differed among sex and age groups, seasons, and sites; and to determine whether the birds were exposed to organophosphorous or carbamate pesticides. Redheads were collected at the beginning and end of the wintering season under the assumption that if accumulation of contaminants occurred on the wintering grounds, concentrations would be greater in late winter than in early winter.

\section{Study Areas}

The Laguna Madre and the Chandeleur Sound sites are classified as estuarine intertidal and subtidal aquatic bed habitat; the Laguna Madre is hyperhaline (ambient salinities $>40 \mathrm{mg} / \mathrm{g}$ ) and Chandeleur Sound is polyhaline $(18-30 \mathrm{mg} / \mathrm{g}$; Cowardin $e t$ al. 1979). These areas are dominated by three species of seagrasses: Halodule wrightii, Thalassia testudinum, and $S y$ ringodium filiformis. Redheads in the areas feed primarily in shallow $(10-30 \mathrm{~cm})$ water where $H$. wrightii is the preferred food but also consume some mollusks (primarily gastropods; McMahan 1970; Cornelius 1977; Mitchell 1992; Michot and Nault 1993; Michot et al. 1994).

The Laguna Madre is about $5-10 \mathrm{~km}$ wide and $225 \mathrm{~km}$ long and is separated from the Gulf of Mexico by Padre and South Padre islands (Figure 1). The Laguna is divided into upper (northern) and lower (southern) sections by a $20-\mathrm{km}$-wide land bridge that connects Padre Island and the mainland; the land bridge is bisected by the Gulf Intracoastal Waterway. The Port Aransas collection site was in Redfish Bay, adjacent to the northern end of the upper Laguna; the Port Mansfield collection site was in the lower Laguna about $15 \mathrm{~km}$ south of Port Mansfield. The distance between the two sites was approximately $160 \mathrm{~km}$, and we assumed little interchange of redheads between 
T. C. Michot et al.

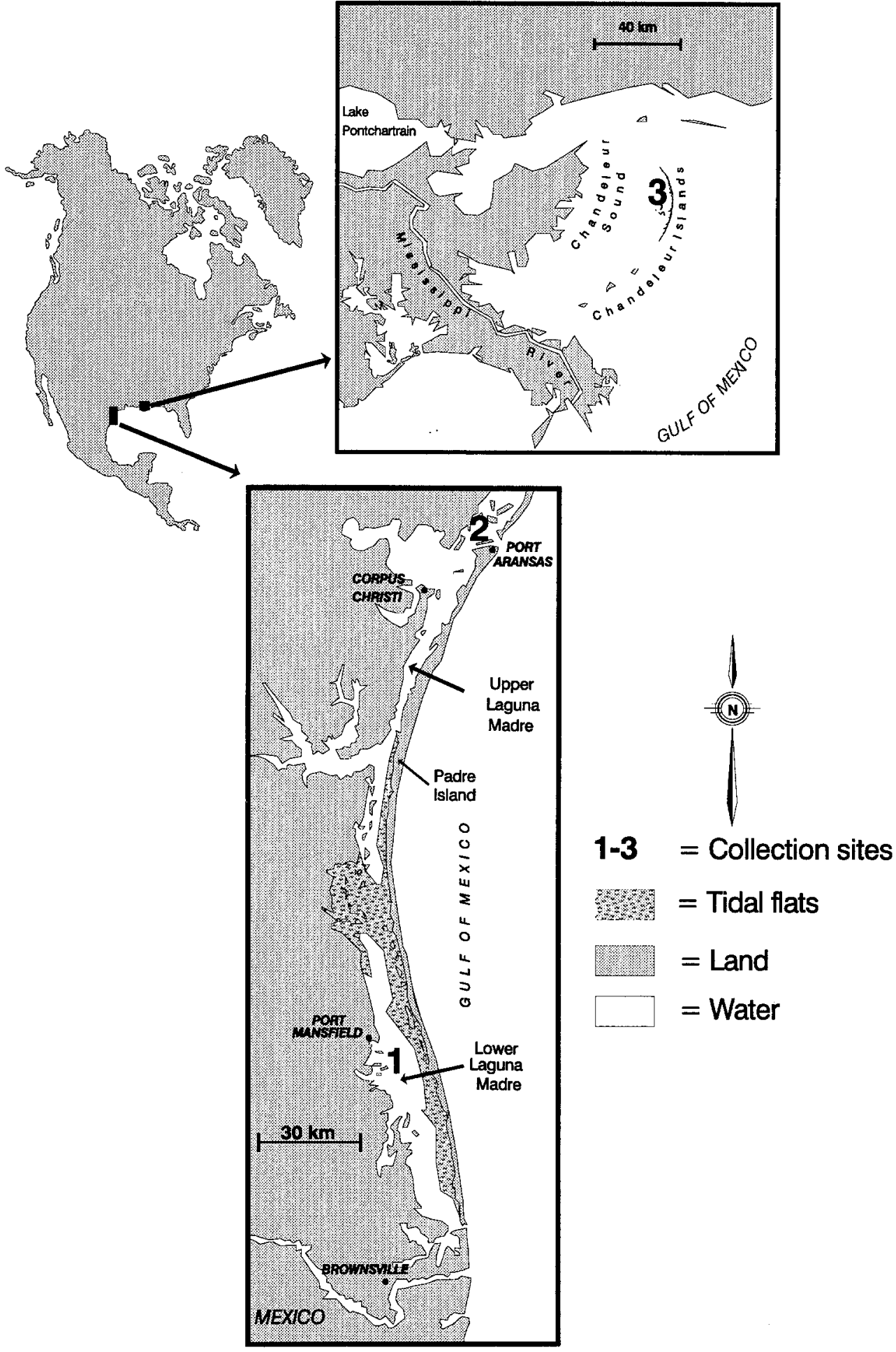

Fig. 1. Vicinity of study area showing location on the North American continent and on the Louisiana and Texas coasts. Collection sites: (1) Port Mansfield, TX; (2) Port Aransas, TX; (3) Chandeleur Sound, LA the two sites (Moore 1991). Agricultural, residential, and industrial areas on the mainland are potential sources for contaminated runoff into the Port Aransas site; agricultural runoff is presumed to be the principal source of contaminants into the Port Mansfield site (Pacheco et al. 1990; Custer and Mitchell 1991, 1993). Redheads obtain drinking water from freshwater ponds adjacent to the Laguna Madre (Adair 1990, Moore 1991,
Mitchell et al. 1992; Woodin 1994) and could pick up contaminants from those sites as well.

The Chandeleur Islands, a 64-km-long barrier chain, separate the Chandeleur Sound from the Gulf of Mexico (Figure 1). We believe that, because of its distance from the mainland ( 40 $\mathrm{km}$ ), this site is relatively free from land-based contaminant sources such as short-lived agricultural pesticides; however, the 
Table 1. Concentrations ( $\mu \mathrm{g} / \mathrm{g}$ dry mass) of trace elements ${ }^{\mathrm{a}}$ in livers of redheads collected at Port Aransas and Port Mansfield,TX and Chandeleur Sound, LA, winter 1987-88

\begin{tabular}{|c|c|c|c|c|c|c|}
\hline Element & $\mathrm{LOD}^{\mathrm{b}}$ & $\begin{array}{l}\text { Percent } \\
\text { detected }^{\mathrm{c}}\end{array}$ & Mean $^{d}$ & $\mathrm{SE}$ & Min & Max \\
\hline$\overline{\text { As }}$ & 0.30 & 77 & $0.59^{\mathrm{ef}}$ & 0.05 & $<0.30$ & 2.70 \\
\hline B & 3.00 & 70 & $4.74^{\mathrm{f}}$ & 0.34 & $<3.00$ & 12.80 \\
\hline $\mathrm{Cd}$ & 0.80 & 51 & $0.91^{\mathrm{g}}$ & 0.11 & $<0.80$ & 5.41 \\
\hline $\mathrm{Hg}$ & 0.02 & 90 & $0.06^{\mathrm{g}}$ & 0.01 & $<0.02$ & 1.53 \\
\hline $\mathrm{Mn}$ & 3.00 & 100 & 7.27 & 0.17 & 3.88 & 11.50 \\
\hline $\mathrm{Se}$ & 0.30 & 100 & $3.19^{\mathrm{e}}$ & 0.11 & 1.56 & 5.85 \\
\hline $\mathrm{Sr}$ & 1.50 & 39 & - & - & $<1.50$ & 5.12 \\
\hline $\mathrm{Cu}$ & 3.00 & 100 & $153^{\mathrm{g}}$ & 20 & 8 & 1030 \\
\hline $\mathrm{Fe}$ & 10.00 & 100 & $2265^{\text {ef }}$ & 170 & 494 & 8210 \\
\hline $\mathrm{Mg}$ & 10.00 & 100 & $631^{\mathrm{f}}$ & 13 & 411 & 933 \\
\hline $\mathrm{Zn}$ & 3.00 & 100 & 122 & 5 & 68 & 337 \\
\hline
\end{tabular}

a No specimens had detectable levels of $\mathrm{Cr}$ (2.0) (LOD), $\mathrm{Ni}$ (4.0), or $\mathrm{Pb}(9.0)$

${ }^{b} \mathrm{LOD}=$ limit of detection

'Percent of observations above LOD, out of a total of 70 birds

${ }^{d}$ For calculation of the mean, observations with values $<$ LOD were assigned a value of LOD/2 ( $\mathrm{Sr}$ mean not shown because $>50 \%$ of observations were below LOD)

${ }^{\text {e}}$ Significant $(\mathrm{P}<0.005)$ seasonal differences were found

${ }^{f}$ Significant $(\mathrm{P}<0.005)$ location differences were found

${ }^{\mathrm{g}}$ Mean and SE of transformed elements were back-transformed. SEs shown are the upper limits; lower limits are: $\mathrm{Cd}, 0.09 ; \mathrm{Cu}, 18.70 ; \mathrm{Hg}, 0.01$

Mississippi River Gulf Outlet (50 km south of the site) and oil and gas structures in the adjacent Gulf of Mexico are potential sources of water-borne pollutants (Demas 1983; Sabourin et al. 1984; Boesch and Rabalais 1989).

\section{Methods}

\section{Sample Collection}

Redheads were collected from land at the Chandeleur Sound $(n=30)$, and over decoys at the Port Aransas $(n=20)$ and Port Mansfield $(n=$ 20) sites with steel shot. Two collections were made at each of the three sites: one in early winter (Nov-Dec 1987) and one in late winter (Feb-Mar 1988); age and sex classes were equally represented (selected from a larger sample of collected birds). Birds were put on ice immediately after collection and were frozen at $<-20^{\circ} \mathrm{C}$ as soon as possible, usually within 2 days ( $\max =6 \mathrm{~d}$ ). The birds were thawed, the feathers were sheared, and feet, wings, and gastrointestinal tracts were removed from the carcasses in the laboratory prior to analysis. Livers and heads were removed and refrozen at $<-20^{\circ} \mathrm{C}$ for subsequent analysis.

\section{Analytical Procedures}

Livers $(n=70)$ were analyzed for trace elements under approved laboratory practices by a contract laboratory of the US Fish and Wildlife Service (Research Triangle Institute, Research Triangle Park, NC). Samples were freeze-dried, weighed, and then homogenized in a blender. Subsamples of freeze-dried livers were digested in stages with heat and nitric-perchloric acid and then analyzed for selenium $(\mathrm{Se})$ and arsenic (As) by hydride-generation atomic absorption spectrophotometry (AAS), and for boron (B), cadmium (Cd), chromium (Cr), copper $(\mathrm{Cu})$, iron $(\mathrm{Fe})$, lead $(\mathrm{Pb})$, magnesium $(\mathrm{Mg})$, manganese $(\mathrm{Mn})$, nickel $(\mathrm{Ni})$, strontium $(\mathrm{Sr})$, and zinc ( $\mathrm{Zn})$ by inductively coupled plasmaatomic emission spectrophotometry. Separate subsamples of the dried livers were digested by nitric acid reflux and analyzed for mercury by cold vapor AAS. Nominal limits of detection (LOD) in $\mu \mathrm{g} / \mathrm{g}$ dry mass are presented in Table 1 .

A set of carcass aliquots $(n=70)$ was analyzed for OCs at the Patuxent Wildlife Research Center, Laurel, Maryland, following the methods described by Cromartic et al. (1975). The minimum limit of detection was $0.30 \mu \mathrm{g} / \mathrm{g}$ unless otherwise noted in parentheses. Samples were analyzed for $p, p^{\prime}$ DDT $(1,1-(2,2,2$-Trichloroethylidene)bis(4-chlorobenzene), $p, p^{\prime} \mathrm{DDE}$ (1,1-dichloro-2,2-bis( $p$-chlorophenyl)ethylene) $(0.10), p, p^{\prime} \mathrm{DDD}$, dieldrin, endrin, heptachlor epoxide, alpha chlordane, cis-nonachlor, trans-nonachlor, PCBs (polychlorinated biphenyls) (1.50), dichloronaphthalene (1.50), tetrachloronaphthalene (1.50), pentachlorodiphenyl ether (1.50), tetrachlorodiphenyl ether (1.50), octachlorostyrene (1.50), and oxychlordane. Silica gel was used for the separation of pesticides from PCBs and to insure isolation of dieldrin and endrin from the remaining OCs (Kaiser $e t$ al. 1980). Pesticides in each silica gel fraction were identified and quantified by packed column $\mathrm{GC}$ and $\mathrm{a}^{63} \mathrm{Ni}$ electron capture detector. Residues in $10 \%$ of the samples were confirmed by $\mathrm{GC} /$ mass spectrometry.

A second set of carcass aliquots $(n=15$; late-winter males only, selected from the total sample) was analyzed for petroleum hydrocarbons under approved good laboratory practices by a contract laboratory of the US Fish and Wildlife Service (Mississippi State Chemical Laboratory, Mississippi State University, Mississippi). Samples were digested in $6 \mathrm{~N}$ aqueous potassium hydroxide for $24 \mathrm{~h}$ at $35^{\circ} \mathrm{C}$. The digestate was cooled and then neutralized with glacial acetic acid. The mixture was extracted three times with methylene chloride, and the extracts were combined and concentrated to near dryness before reconstituting in petroleum ether for transfer to a $20 \mathrm{~g} 1 \%$ deactivated silica gel column topped with $5 \mathrm{~g}$ neutral alumina. Aliphatic hydrocarbons (AHs) and polynuclear aromatic hydrocarbons (PAHs) were separated by eluting AHs from the column with $100 \mathrm{ml}$ of petroleum ether; PAHs were eluted using $100 \mathrm{ml} 40 \%$ methylene chloride $/ 60 \%$ petroleum ether followed by $50 \mathrm{ml}$ methylene chloride. The AH eluate was concentrated to an appropriate volume for quantification by capillary column flame ionization gas chromatography (GC). The silica gel eluate containing the PAHs was concentrated and reconstituted in methylene chloride to be subjected to gel permeation chromatography cleanup prior to quantification by GC and fluorescence high-performance liquid chromatography. Minimum detection limits for HCs were $0.01 \mu \mathrm{g} / \mathrm{g}$. 
Concentrations of trace elements are reported on a dry mass basis; approximate wet-mass values can be calculated by using the mean percent moisture value of $71.45 \%$ for livers from this study. Concentrations of organochlorines and hydrocarbons are reported on a wetmass basis.

Whole brain cholinesterase (ChE) activity was assayed on longitudinally bisected half-brains $(\mathrm{n}=43)$ as described by Ellman et al. (1961) and modified by Hill and Fleming (1982). The reaction rate was measured on a Bausch \& Lomb Spectronic 70 spectrophotometer, with acetylthiocholine iodide as the substrate. All assays were run on the same day at a wavelength of $405 \mathrm{~nm}$. Control samples were run throughout the day to minimize any effects of temperature variation. An average brain $\mathrm{ChE}$ activity was calculated from two replicate measurements. Brain $\mathrm{ChE}$ activity is expressed as $\mu$ moles acetylthiocholine iodide hydrolyzed $/ \mathrm{min} / \mathrm{g}$ of brain tissue (wet mass).

\section{Statistical Procedures}

Values for $\mathrm{Cd}, \mathrm{Hg}$, and the three hydrocarbon ratios were log-transformed and $\mathrm{Cu}$ was square-root transformed to satisfy the assumptions of analysis of variance (ANOVA), i.e., homogeneity of variance among groups. For observations with contaminant concentrations below the LOD (i.e., censored data, sensu Rhodes 1981; Gilbert 1987; Shumway et al. 1989), a value of LOD/2 was assigned for the calculation of means (Paasivirta 1991). If $>50 \%$ of the observations were $<$ LOD, no statistical analyses (means, SEs, ANOVAs) were conducted. The number of observations in each cell was not sufficient to run a 4-way factorial ANOVA. Therefore, we tested for sex differences within location/season/age cells where samples were adequate. Having found no sex differences, we pooled observations over sexes and conducted a 3-way factorial ANOVA (SAS-GLM; SAS Institute 1987) for each element, compound (DDE), or ChE activity, with location, season, and age as independent variables. ANOVAs were then rerun with sex introduced and age removed from the model to ensure against any confounding sex effect. Hydrocarbons were only tested for location differences. A conservative alpha level of 0.005 was used for each pairwise comparison to achieve an experimentwise Type I error rate of 0.05 (Day and Quinn 1989).

For the HC analysis, we calculated, in addition to mean for each compound, several ratios and totals. Pristane and phytane are branchchained compounds that occur commonly in petroleum pollutants and may be metabolized less readily than straight-chained configurations (Hall and Coon 1988). Therefore, we calculated the ratios of pristane: $n$-heptadecane, phytane: $n$-octadecane, and pristane:phytane under the assumption that ratio values of $>1$, for the first two terms, would indicate chronic exposure to petroleum pollutants (Hall and Coon 1988; Rattner et al. 1993). We also calculated total AHs, total PAHs, and total HCs as the sum of all detectable compounds in each group (Rattner et al. 1993).

\section{Results}

Eleven of the 14 measured trace elements (Table 1) and only one OC (DDE) of the measured 16 were detected in our samples. Twenty of $27 \mathrm{HCs}$ had concentrations greater than the LOD (Table 2). Neither age nor sex differences were indicated for any of the elements or compounds analyzed.

We found seasonal differences for As, Fe, and Se (Table 3): (1) As was higher in immature early-winter birds than in immature late-winter birds at Port Mansfield; (2) Fe in Port Mansfield birds was higher in both age groups for early compared to late winter; and (3) Se increased from early winter to late winter for both age groups at Port Aransas.
Four trace elements differed by location. Concentrations of As in early winter were higher in Port Mansfield adults and immatures than in Port Aransas birds (Table 3). Concentrations of B at Port Aransas exceeded those at Chandeleur Sound and Port Mansfield for late-winter immatures (Table 4). Late-winter birds from Port Mansfield were lower in Fe than Chandeleur Sound adults and Port Aransas immatures (Table 3). Port Mansfield late-winter immatures also had lower $\mathrm{Mg}$ levels than Chandeleur Sound and Port Aransas birds (Table 4). There were no seasonal or location differences for $\mathrm{Cd}, \mathrm{Cu}, \mathrm{Hg}, \mathrm{Mn}$, $\mathrm{Sr}$, and $\mathrm{Zn}$.

Fifty-four of 70 ducks had concentrations of DDE that were greater than the LOD $(0.3 \mu \mathrm{g} / \mathrm{g})$; the overall mean was $0.47 \pm$ 0.12 (SE), and the maximum value was $7.10 \mu \mathrm{g} / \mathrm{g}$. This compound showed locational, but not seasonal, differences. Port Mansfield birds had higher concentrations of DDE in late winter than Chandeleur Sound or Port Aransas birds (Table 5). Port Aransas early-winter adults had higher levels than Chandeleur Sound early-winter adults.

Seven of 14 PAHs and all of 13 AHs were detected (Table 2). Two of the compounds differed by location. Concentrations of $N$-hexadecane and $n$-nonadecane were higher in Port Aransas birds than in birds from Port Mansfield or Chandeleur Sound (Table 5). Aliphatic ratios are shown in Table 2; there were no significant location differences. Chrysene levels were highest at Chandeleur Sound [0.024 \pm 0.005 (SE)] where all five birds were greater than LOD; only two birds at Port Aransas and none at Port Mansfield had levels $>$ LOD. There were no significant location differences for total AHs, total PAHs, or total HCs.

Mean brain cholinesterase activity did not differ among locations, between seasons, or between sexes; there were no significant interactions. The mean brain cholinesterase activity was $9.03 \pm 0.13(\mathrm{SE} ; \mathrm{n}=43 ; \min =7.5, \max =11.6) \mu \mathrm{mol}$ acetylthiocholine iodide hydrolyzed $/ \mathrm{min} / \mathrm{g}$ brain tissue (wet mass).

\section{Discussion}

Concentrations of contaminants in redheads from the three sites were generally low. Twenty-five (44\%) of the 57 tested elements or compounds were not detected. Although no significant differences were found in sex or age, differences in location or season of some contaminants were not consistent for both age groups. Differences in physiology, feeding ecology, or bioaccumulation rates may explain those inconsistencies.

Eight contaminants showed significant location differences; four of those (HCs) were not tested among sex and age groups. Of the four remaining, two (As, DDE) were consistent for both age groups, and none was consistent among both age and seasonal groups. This indicates that the location differences were weak or not persistent enough over time to show up in all groups. Port Aransas had higher contaminant levels than one or both of the other two locations for six elements or compounds, whereas the Chandeleur Sound and Port Mansfield had higher levels for only three and two contaminants, respectively. This may be related to the high number of point-source discharge sites near Corpus Christi (Pacheco et al. 1990).

Three of 30 contaminants showed differences between earlywinter and late-winter birds, but none held true for all locations and age groups; two were consistent for both age groups within a single location. Only one of those (Se) showed an increase 
Table 2. Body burdens ( $\mu \mathrm{g} / \mathrm{g}$ wet mass) of hydrocarbons ${ }^{\mathrm{a}}$ in late-winter male redheads collected at Port Aransas and Port Mansfield, TX and Chandeleur Sound, LA, winter 1987-88

\begin{tabular}{|c|c|c|c|c|c|}
\hline $\begin{array}{l}\text { Chemical class } \\
\text { Compound }\end{array}$ & $\begin{array}{l}\text { Percent } \\
\text { detected }^{b}\end{array}$ & $\operatorname{Mean}^{c}$ & $\mathrm{SE}$ & Min & $\operatorname{Max}$ \\
\hline \multicolumn{6}{|l|}{ Aliphatics $(\mathrm{AH})$} \\
\hline$N$-dodecane & 100 & 0.032 & 0.003 & 0.02 & 0.07 \\
\hline$N$-eicosane & 100 & 0.054 & 0.005 & 0.03 & 0.10 \\
\hline$N$-heptadecane & 100 & 0.151 & 0.036 & 0.01 & 0.61 \\
\hline$N$-hexadecane & 100 & $0.058^{\mathrm{d}}$ & 0.005 & 0.04 & 0.10 \\
\hline$N$-nonadecane & 100 & $0.085^{\mathrm{d}}$ & 0.007 & 0.05 & 0.14 \\
\hline$N$-octadecane & 100 & 0.030 & 0.002 & 0.02 & 0.04 \\
\hline Nonylcyclohexane & 13 & - & - & $<0.01$ & 0.01 \\
\hline$N$-pentadecane & 100 & 0.174 & 0.013 & 0.07 & 0.28 \\
\hline$N$-tetradecane & 100 & 0.348 & 0.023 & 0.23 & 0.60 \\
\hline$N$-tridecane & 100 & 0.045 & 0.003 & 0.01 & 0.07 \\
\hline Octylcyclohexane & 7 & - & - & $<0.01$ & 0.01 \\
\hline Phytane & 100 & 0.020 & 0.003 & 0.01 & 0.06 \\
\hline Pristane & 93 & 0.047 & 0.024 & $<0.01$ & 0.38 \\
\hline Pristane: $n$-heptadecane & 93 & $0.237^{\mathrm{e}}$ & 0.124 & 0 & 38.00 \\
\hline Pristane:phytane & 93 & $1.461^{\mathrm{e}}$ & 0.530 & 0 & 19.00 \\
\hline Phytane: $n$-octadecane & 100 & $0.599^{\mathrm{e}}$ & 0.079 & 0.33 & 2.00 \\
\hline Total aliphatics & 100 & 1.045 & 0.060 & 0.76 & 1.55 \\
\hline \multicolumn{6}{|l|}{ Aromatics (PAH) } \\
\hline Anthracene & 13 & - & - & $<0.01$ & 0.01 \\
\hline Benzo(e)pyrene & 27 & - & - & $<0.01$ & 0.01 \\
\hline Chrysene & 47 & - & - & $<0.01$ & 0.04 \\
\hline Fluoranthrene & 27 & - & - & $<0.01$ & 0.01 \\
\hline Naphthalene & 27 & - & - & $<0.01$ & 0.01 \\
\hline Phenanthrene & 73 & 0.009 & 0.001 & $<0.01$ & 0.01 \\
\hline Pyrene & 20 & - & - & $<0.01$ & 0.01 \\
\hline Total aromatics & 100 & 0.028 & 0.006 & 0.01 & 0.09 \\
\hline Total Hydrocarbons & 100 & 1.073 & 0.059 & 0.77 & 1.56 \\
\hline
\end{tabular}

a No ducks had detectable levels of benzo(a)pyrene, benzo(b)fluoranthrene, benzo(g,h,i)perylene, benzo(k)fluoranthrene, 1,2-benzanthracene, 1,2,5,6-dibenzanthracene, or fluorene

${ }^{b}$ Percent of observations above limit of detection (LOD), out of 15 birds

${ }^{c}$ For calculation of the mean, observations with values $<$ LOD were assigned a value of LOD/2; for means of totals, only detected compounds were used

${ }^{\mathrm{d}}$ Significant $(\mathrm{P}<0.005)$ location differences were found

e Means and SEs of transformed compounds were back-transformed. SEs shown are the upper limits; lower limits are: pristane: $n$-heptadecane, 0.081 ; pristane:phytane, 0.390 ; phytane: $n$-octadecane, 0.070

from early to late winter; the other $(\mathrm{Fe})$ showed a decrease. Thus, for all 16 OCs and 13 of 14 trace elements, we failed to demonstrate that contaminants were being accumulated on the wintering grounds.

\section{Trace Elements}

Concentrations of As in livers from redheads were low and below the suggested background concentration (i.e., equivalent to concentrations present in birds from uncontaminated areas) of $\leqslant 5.0 \mu \mathrm{g} / \mathrm{g}$ dry mass (Eisler 1988). Similar concentrations of As (mean $=0.52, \max =1.04 \mu \mathrm{g} / \mathrm{g}$ dry mass) were found in livers of redheads collected in coastal Texas (Redfish Bay and Baffin Bay) by LR Gamble and MC Woodin (US Fish Wildl Serv, unpubl data). Highest As levels in our study were in early-winter redheads from Port Mansfield. However, the decreased levels in late winter would indicate that the source of As was not on the wintering grounds.

Late-winter immature redheads at Port Aransas had higher B levels than those from other locations, possibly from point source discharges (Pacheco et al. 1990). Concentrations of B (mean $=5.84, \max =12.80 \mu \mathrm{g} / \mathrm{g}$ dry mass) reported for redheads from Texas by LR Gamble and MC Woodin (US Fish Wildl Serv, unpubl data) were similar to our values. Hoffman et al. (1990) found mallard (Anas platyrhynchos) ducklings with liver concentrations of $1-5 \mu \mathrm{g} / \mathrm{g}$ dry mass B (from B-contaminated diets) to have reduced growth rates and food consumption rates. Additionally, Smith and Anders (1989) found mallard ducklings from hens fed a B-laden diet to have decreased growth rates when fed $30 \mu \mathrm{g} / \mathrm{g}$ B. Concentrations of B in livers of those ducklings ranged from $<3$ to $5 \mu \mathrm{g} / \mathrm{g}$; many of the birds in our study had values higher than that.

Concentrations of $\mathrm{Cd}$ in livers of redheads from this study were generally within background levels. However, 11 of 70 redheads had concentrations above that considered background in livers of waterfowl $(<3 \mu \mathrm{g} / \mathrm{g}$ dry mass, DiGiulio and Scanlon 1984; Scheuhammer 1987). Concentrations of $\mathrm{Cd}$ in birds from our study were approximately the same as concentrations found by LR Gamble and MC Woodin (US Fish Wildl Serv, unpubl data) in wintering redheads from the upper Laguna Madre region of Texas (mean $=1.90, \max =5.27 \mu \mathrm{g} / \mathrm{g}$ dry mass). We found no differences among location, season, age, or sex groups. Much higher Cd concentrations were found by 
Table 3. Liver concentrations ( $\mu \mathrm{g} / \mathrm{g}$ dry mass; mean $\pm \mathrm{SE}$ ) of $\mathrm{As}, \mathrm{Fe}$, and Se, by age and season, from redheads collected at Port Mansfield and Port Aransas, TX and Chandeleur Sound, LA, winter 1987-88

\begin{tabular}{|c|c|c|c|c|c|c|c|}
\hline \multirow{3}{*}{$\begin{array}{l}\text { Element } \\
\text { Age } \\
\text { Season }\end{array}$} & \multirow{3}{*}{\multicolumn{2}{|c|}{$\begin{array}{l}\text { Port } \\
\text { Mansfield }\end{array}$}} & \multirow{3}{*}{\multicolumn{2}{|c|}{$\begin{array}{l}\text { Port } \\
\text { Aransas }\end{array}$}} & & & \\
\hline & & & & & \multicolumn{2}{|l|}{ Chandeleur } & \\
\hline & & & & & \multicolumn{2}{|l|}{ Sound } & Signif. $^{\mathrm{a}}$ \\
\hline \multicolumn{8}{|l|}{ As } \\
\hline \multicolumn{8}{|l|}{ Adults } \\
\hline Early & $0.90 \pm$ & $0.17(6 / 6)^{b}$ & $0.27 \pm$ & $0.06(3 / 7)$ & $0.58 \pm$ & $0.12(5 / 7)$ & A B AB \\
\hline Late & $0.55 \pm$ & $0.12(5 / 6)$ & $0.55 \pm$ & $0.05(3 / 3)$ & $0.58 \pm$ & $0.27(4 / 6)$ & $\mathrm{AAA}$ \\
\hline Signif. $^{c}$ & \multicolumn{2}{|c|}{ NSD } & \multicolumn{2}{|c|}{ NSD } & \multicolumn{2}{|c|}{ NSD } & \\
\hline \multicolumn{8}{|l|}{ Immatures } \\
\hline Early & $1.46 \pm$ & $0.43(4 / 4)$ & $0.57 \pm$ & $0.13(3 / 3)$ & $0.82 \pm$ & $0.18(7 / 7)$ & A B AB \\
\hline Late & $0.59 \pm$ & $0.15(3 / 4)$ & $0.34 \pm$ & $0.06(5 / 7)$ & $0.34 \pm$ & $0.06(6 / 10)$ & $\mathrm{AAA}$ \\
\hline Signif. & \multicolumn{2}{|c|}{ SD } & \multicolumn{2}{|c|}{ NSD } & \multicolumn{2}{|c|}{ NSD } & \\
\hline \multicolumn{8}{|l|}{$\mathrm{Fe}$} \\
\hline \multicolumn{8}{|l|}{ Adults } \\
\hline Early & 2293 & $\pm 298(6 / 6)$ & 1825 & $\pm 326(7 / 7)$ & \multicolumn{2}{|c|}{ $\pm 130(7 / 7)$} & $\mathrm{A} A \mathrm{~A}$ \\
\hline Late & 1003 & $26(6 / 6)$ & 1717 & $14(3 / 3)$ & 3768 & $12(6 / 6)$ & $\mathrm{B} A \mathrm{AB}$ \\
\hline Signif. & \multicolumn{2}{|c|}{ SD } & \multicolumn{2}{|c|}{ NSD } & \multicolumn{2}{|c|}{ NSD } & \\
\hline \multicolumn{8}{|l|}{ Immatures } \\
\hline Early & 3127 & $\pm 207(4 / 4)$ & 1990 & $\pm 308(3 / 3)$ & \multicolumn{2}{|c|}{ $\pm 629(7 / 7)$} & A A A \\
\hline Late & 946 & $54(4 / 4)$ & 2896 & $25(7 / 7)$ & 1693 & $04(10 / 10)$ & $\mathrm{B} A \mathrm{AB}$ \\
\hline Signif. & \multicolumn{2}{|c|}{ SD } & \multicolumn{2}{|c|}{ NSD } & \multicolumn{2}{|c|}{ NSD } & \\
\hline \multicolumn{8}{|l|}{$\mathrm{Se}$} \\
\hline Adults & & & & & & & \\
\hline Early & $2.74 \pm$ & $0.25(6 / 6)$ & $2.58 \pm$ & $0.39(7 / 7)$ & $3.20 \pm$ & $0.52(7 / 7)$ & A A A \\
\hline Late & $3.07 \pm$ & $0.11(6 / 6)$ & $4.50 \pm$ & $0.41(3 / 3)$ & $3.09 \pm$ & $0.18(6 / 6)$ & $\mathrm{A} A \mathrm{~A}$ \\
\hline Signif. & & & & & & SD & \\
\hline Immatures & & & & & & & \\
\hline Early & $2.50 \pm$ & $0.32(4 / 4)$ & $2.30 \pm$ & $0.05(3 / 3)$ & $3.12 \pm$ & $0.28(7 / 7)$ & $\mathrm{AAA}$ \\
\hline Late & $2.92 \pm$ & $0.18(4 / 4)$ & $3.97 \pm$ & $0.21(7 / 7)$ & $3.74 \pm$ & $0.31(10 / 10)$ & $\mathrm{AAA}$ \\
\hline Signif. & & & & & & SD & \\
\hline
\end{tabular}

${ }^{a}$ Cells with a common letter do not vary significantly $(\mathrm{P}<0.005)$ among locations

${ }^{b}$ Number of observations $>$ LOD/total number of observations

${ }^{\mathrm{c}} \mathrm{NSD}=$ no significant difference, $\mathrm{SD}=$ significant difference $(\mathrm{P}<0.005)$, between seasons within age groups

Lande (1977) in eiders (Somateria mollissima) from a polluted fjord $($ mean $=13.0 \mu \mathrm{g} / \mathrm{g}$ dry mass) and by Vermeer and Castilla (1991) in shorebirds collected adjacent to a copper mine discharge site (3.3-219 $\mu \mathrm{g} / \mathrm{g}$ dry mass, assuming $70 \%$ moisture).

Although redheads do not seem to be accumulating $\mathrm{Cu}$ on the wintering grounds, the concentrations of $\mathrm{Cu}$ in our birds were higher than the concentrations reported by Ohlendorf et al. (1986) in surf scoters (Melanitta perspicillata; mean $=49.8$, $\max =110 \mu \mathrm{g} / \mathrm{g}$ dry mass) and greater scaup (Aythya marila; mean $=96.8, \max =159.0 \mu \mathrm{g} / \mathrm{g}$ dry mass $)$, which they considered elevated. We also had many individuals with values higher than those reported for canvasbacks (Aythya valisineria) in Louisiana (mean $=136, \max =2,080 \mu \mathrm{g} / \mathrm{g}$ dry mass; Custer and Hohman 1993). L. R. Gamble and M. C. Woodin (US Fish Wildl Serv, unpubl data) found levels similar to ours in redheads from Texas (mean $=310, \max =1290 \mu \mathrm{g} / \mathrm{g}$ dry mass). Concentrations of $\mathrm{Cu}$ (mean $=367 \mu \mathrm{g} / \mathrm{g}$ dry mass; Lande 1977 ) in eiders (Somateria mollissima) from a polluted Norway fjord were higher than in redheads from our study. High values in our study may be the result of $\mathrm{Cu}$ accumulations in sediments near produced water discharges from oil and gas production (Boesch and Rabalais 1989; St. Pé 1990).

Iron showed a consistent decrease from early winter to late winter at Port Mansfield for both age groups. This indicates that birds there were subjected to higher levels of Fe prior to their arrival on the wintering grounds. Elevated levels may be present throughout the winter at Port Aransas and Chandeleur Sound, which would explain the lack of significant seasonal differences at those sites and the relatively lower values in late winter at Port Mansfield. Both Fe overload and Fe deficiency can be pathological in birds (Irby et al. 1967; Locke et al. 1967; Scott et al. 1976; Lowenstine and Petrak 1980). The low Fe concentrations we found in late-winter redheads from Port Mansfield were within the range (524-1,360 $\mu \mathrm{g} / \mathrm{g}$ dry mass assuming $70 \%$ moisture; Locke et al. 1967) of normal livers from control birds in an experimental study of $\mathrm{Fe}$ shot ingestion in pen-reared mallards. Most individuals from our other two sites and from Port Mansfield early winter, however, had liver Fe concentrations equivalent to those (range $=1,311-8,758$ $\mu \mathrm{g} / \mathrm{g}$ dry mass assuming $70 \%$ moisture) in mallards from the same study that exhibited extensive hemosiderosis of the liver after receiving experimental doses of uncoated Fe shot. Concentrations of $\mathrm{Fe}$ in birds from all three of our study sites were lower than concentrations in livers from female canvasbacks collected at two locations in Louisiana (mean $=4,335$, $\max =$ $22,800 \mu \mathrm{g} / \mathrm{g}$ dry mass; Custer and Hohman, US Fish Wildl Serv, unpubl data).

No birds had $\mathrm{Pb}$ liver values above the detection limit $(9 \mu \mathrm{g} / \mathrm{g}$ dry mass); however, some values could have been elevated (6.7-9 $\mu \mathrm{g} / \mathrm{g}$ dry mass, Friend 1985) and not measured. Our results differ from L. R. Gamble and M. C. Woodin (US Fish 
Table 4. Liver concentrations ( $\mu \mathrm{g} / \mathrm{g}$ dry mass; mean $\pm \mathrm{SE}$ ) of $\mathrm{B}$ and $\mathrm{Mg}$, by age and season, from redheads collected at Port Mansfield and Port Aransas, TX and Chandeleur Sound, LA, winter 1987-88

\begin{tabular}{|c|c|c|c|c|}
\hline \multicolumn{5}{|l|}{ Element } \\
\hline Age & \multirow{2}{*}{$\begin{array}{l}\text { Port } \\
\text { Mansfield }\end{array}$} & \multirow{2}{*}{$\begin{array}{l}\text { Port } \\
\text { Aransas }\end{array}$} & Chandeleur & \\
\hline Season & & & Sound & Signif. $^{a}$ \\
\hline \multicolumn{5}{|l|}{$\overline{\mathbf{B}}$} \\
\hline \multicolumn{5}{|l|}{ Adults } \\
\hline Early & $2.80 \pm 0.59(3 / 6)^{b}$ & $3.06 \pm 0.65(4 / 7)$ & $4.03 \pm 0.92(7 / 4)$ & $\mathrm{A} A \mathrm{~A}$ \\
\hline Late & $4.86 \pm 0.30(6 / 6)$ & $5.26 \pm 1.93(2 / 3)$ & $6.52 \pm 1.75(4 / 6)$ & A A A \\
\hline Signif. ${ }^{c}$ & NSD & NSD & NSD & \\
\hline \multicolumn{5}{|l|}{ Immatures } \\
\hline Early & $4.49 \pm 0.30(4 / 4)$ & $3.93 \pm 1.31(2 / 3)$ & $6.30 \pm 0.57(7 / 7)$ & A A A \\
\hline Late & $2.49 \pm 0.99(1 / 4)$ & $8.70 \pm 1.03(7 / 7)$ & $3.70 \pm 0.89(5 / 10)$ & B A B \\
\hline Signif. & NSD & NSD & NSD & \\
\hline \multicolumn{5}{|l|}{$\mathrm{Mg}$} \\
\hline \multicolumn{5}{|l|}{ Adults } \\
\hline Early & $\pm 29(6 / 6)$ & $\pm 22(7 / 7)$ & $\pm 37(7 / 7)$ & A A A \\
\hline Late & $\pm 29(6 / 6)$ & $\pm 41(3 / 3)$ & $\pm 41(6 / 6)$ & $\mathrm{A} A \mathrm{~A}$ \\
\hline Signif. & \multirow[t]{2}{*}{ NSD } & NSD & \multirow[t]{2}{*}{ NSD } & \\
\hline \multicolumn{3}{|l|}{ Immatures } & & \\
\hline Early & $\pm 34(4 / 4)$ & $\pm 29(3 / 3)$ & $\pm 45(7 / 7)$ & A A A \\
\hline Late & $\pm 30(4 / 4)$ & $\pm 23(7 / 7)$ & $\pm 30(10 / 10)$ & $\mathrm{B}$ A A \\
\hline Signif. & NSD & NSD & \multicolumn{2}{|l|}{ NSD } \\
\hline
\end{tabular}

${ }^{a}$ Cells with a common letter do not vary significantly $(P<0.005)$ among locations

${ }^{b}$ Number of observations $>$ LOD/total number of observations

${ }^{\mathrm{N} S D}=$ no significant difference $(\mathrm{P}>0.005)$ between seasons within age groups

Table 5. Body burdens ( $\mu \mathrm{g} / \mathrm{g}$ wet mass; mean $\pm \mathrm{SE}$ ) for selected organochlorines and hydrocarbons in redheads collected at Port Mansfield and Port Aransas, TX and Chandeleur Sound, LA, winter 1987-88

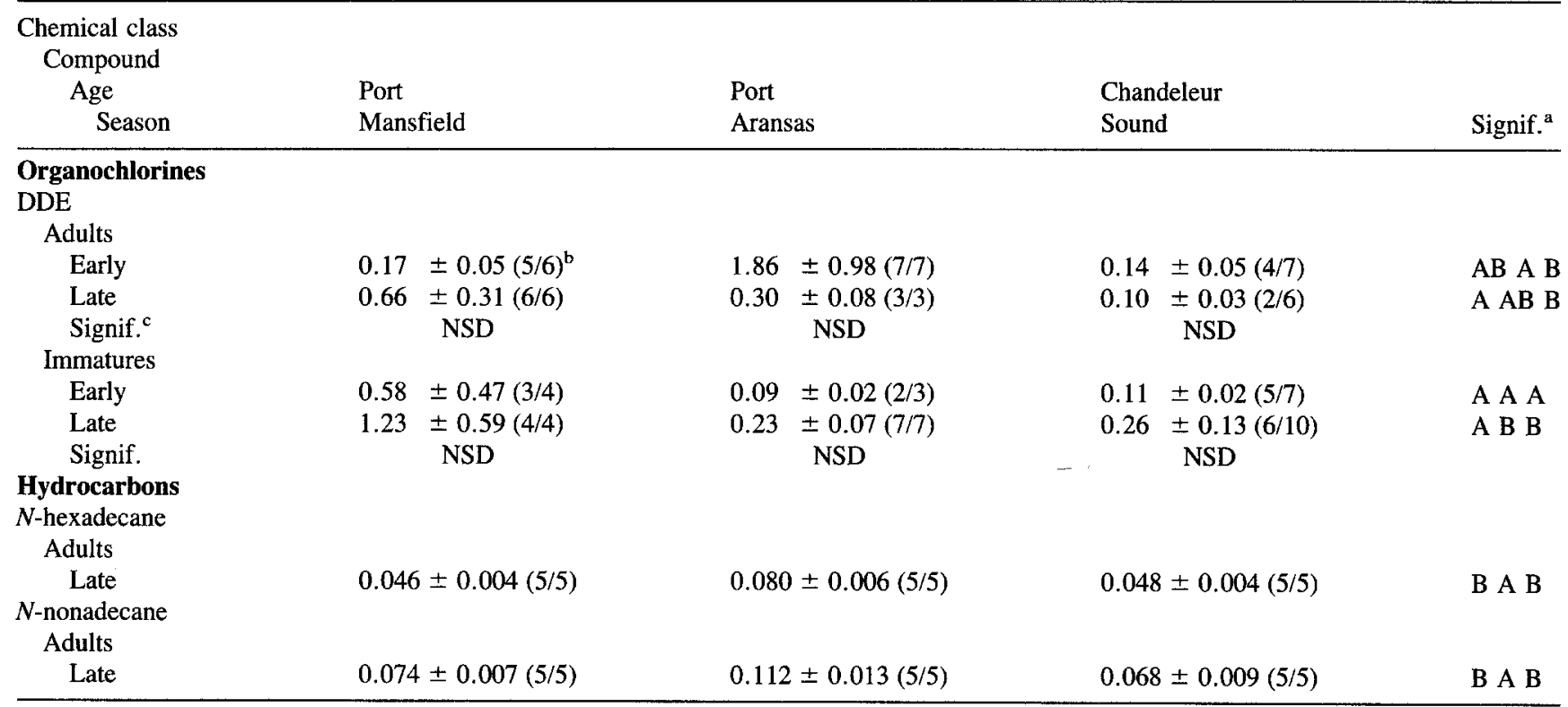

${ }^{a}$ Cells with a common letter do not vary significantly $(P<0.005)$ among locations

${ }^{b}$ Number of observations $>$ LOD/total number of observations

${ }^{c} \mathrm{NSD}=$ no significant difference $(P>0.005)$ between seasons within age groups

Wildl Serv, unpubl data), who found two out of 40 redheads collected in Texas (both from Redfish Bay) to have $\mathrm{Pb}$ levels (39.8 and $46.3 \mu \mathrm{g} / \mathrm{g}$ dry mass) indicating toxicosis $(>26.7$ $\mu \mathrm{g} / \mathrm{g}$; Friend 1985); however, levels of their other specimens were low $(<1.00-5.37 \mu \mathrm{g} / \mathrm{g}$ dry mass).

Selenium in redheads from the Port Aransas site was the only contaminant with a consistent increase from early to late winter in both age groups. Concentrations of $\mathrm{Se}$ in birds from this study were lower than levels found in willets (Catoptrophorus semipalmatus) collected during the summer at Port Mansfield (mean $=5.5, \max =8.3 \mu \mathrm{g} / \mathrm{g}$ dry mass; Custer and Mitchell 1991). Paveglio et al. (1992) considered background levels of Se to be between 2.0 and $5.0 \mu \mathrm{g} / \mathrm{g}$ dry mass in other waterfowl. Concentrations of Se in livers of several bird species from freshwater habitats ranged from 4 to $10 \mu \mathrm{g} / \mathrm{g}$ and were considered to be at background levels (Ohlendorf 1989). Neverthe- 
less, the higher Se levels that we detected in late-winter birds from Port Aransas could have originated from local sources. $L$. R. Gamble and M. C. Woodin (US Fish Wildl Serv, unpubl data) also found a significant increase in Se between earlywinter (median $=2.54 \mu \mathrm{g} / \mathrm{g}$ dry mass) and late-winter (median $=3.65 \mu \mathrm{g} / \mathrm{g}$ dry mass) redheads collected in Redfish Bay, Texas, at the same location where our Port Aransas collections were made.

Magnesium, $\mathrm{Mn}, \mathrm{Hg}$, and $\mathrm{Zn}$ were generally at background levels. Values from our study were similar to or lower than concentrations found in canvasbacks from Louisiana (Custer and Hohman 1993) and Chesapeake Bay (White et al. 1979); greater scaup and surf scoters from the Pacific Coast (Ohlendorf et al. 1986); seabirds from the Atlantic Coast (Elliot et al. 1992); or in other redheads from Texas (L. R. Gamble and M. C. Woodin, US Fish Wildl Serv, unpubl data). Few references are available on the effects of Sr levels in wildlife, and possible effects of the levels we found in this study are unknown.

\section{Organochlorines, Hydrocarbons, and Brain Cholinesterase}

Concentrations of DDE in carcasses from redheads were relatively low, though several were higher than concentrations $(<0.5 \mu \mathrm{g} / \mathrm{g})$ in waterfowl used as controls in feeding studies (Haegele and Hudson 1974; Longcore and Stendell 1977). However, the concentrations found in our birds are lower than those thought to impair survival or reproduction (Ohlendorf and Miller 1984; Mora et al. 1987; Ford and Hill 1990). Highest levels in our study were at the Port Aransas and Port Mansfield sites. The location differences were not consistent among age or seasonal groups, but the higher values shown for Port Mansfield adults and immatures in late winter may be related to the high incidence of agricultural activities in the lower Laguna Madre area (Custer and Mitchell 1987; Custer and Mitchell 1993).

The paucity of detectable PAHs [which are common in petroleum compounds and rare in uncontaminated animal tissue (Hall and Coon 1988)], indicate that our collection sites were not heavily polluted with the HCs we measured. However, St. Pé (1990) found that petroleum-contaminated sites had higher concentrations of some PAH's not measured in this study (e.g., the alkylated homologs $\mathrm{C}-1, \mathrm{C}-2$, and $\mathrm{C}-3$ naphthalene and phenanthrene) than of the parent groups measured herein; thus, petroleum contamination on our sites cannot be ruled out.

Concentrations of total AHs and PAHs were several times lower than levels reported in double-crested cormorants ( $\mathrm{Pha}$ lacrocorax auritus) collected in February in the Houston Ship Channel, Texas (King et al. 1987; AHs mean $=8.2$, $\max =$ $29.3 \mu \mathrm{g} / \mathrm{g}$ wet mass; PAHs mean $=1.1, \max =1.2 \mu \mathrm{g} / \mathrm{g}$ wet mass). These differences are even more extreme because the cormorants, in contrast to the redheads, were skinned prior to analysis, and the highest concentrations of HCs occur in skin and underlying adipose tissue (Lawler et al. 1978); in addition, the cormorants feed at higher trophic levels and would thus be subject to greater bioaccumulation.

Our values of pristane and total HCs were higher than values (pristane: mean $=0.028, \max =0.08 \mu \mathrm{g} / \mathrm{g}$ wet mass; total HCs: mean $=0.820, \max =1.40 \mu \mathrm{g} / \mathrm{g}$ wet mass) in cotton rats (Sigmodon hispidus) from a contaminated petroleum waste site (Rattner et al. 1993). These differences could be related to the tendency of some contaminants to be more persistent, and more toxic, in birds than in mammals because birds have lower activity levels of some enzymes important in breaking down and clearing toxicants from the body (Walker and El Zorgani 1974; Brealey et al. 1980; Westlake et al. 1983).

The mean phytane: $n$-octadecane ratio from our study was less than that found in the fat of a mallard killed by an oil spill (1.1 $\mu \mathrm{g} / \mathrm{g}$ wet mass; Hall and Coon 1988), but was greater than levels in cotton rats from a waste site (mean $=0.257$; Rattner $e t$ al. 1993), and thus may indicate chronic exposure to petroleum products. Our pristane: $n$-heptadecane ratio was approximately the same as that in mallards that were experimentally oiled (mean $=0.238$; Lawler et al. 1978) and was less than that in the fat of a mallard killed by an oil spill (1.6; Hall and Coon 1988). The pristane:phytane ratio in our study was similar to the value (1.321) Rattner et al. (1993) found in cotton rats from their uncontaminated reference site. The higher $\mathrm{HC}$ levels that we found in late-winter males from Port Aransas ( $n$-hexadecane and $n$-nonadecane) and from the Chandeleur Sound (chrysene) may indicate contaminant sources such as produced water discharges in those areas (Boesch and Rabalais 1989; St. Pé 1990).

Based on brain cholinesterase activity, redheads were not recently exposed to organophosphorous or carbamate pesticides. Brain cholinesterase is often used as an indicator of exposure to anti-cholinesterase chemicals, including organophosphate and carbamate pesticides (Ludke et al. 1975; Hill and Fleming 1982; Hill and Murray 1987; Hill 1989, 1992). Brain cholinesterase values below 2 standard deviations of a control mean indicate probable recent exposure to a cholinesterase inhibitor; however, all of the individuals in this study were within the bounds presented by Hill (1988) of apparently normal wild redheads [i.e., 7-13 $\mu \mathrm{mol}$ acetylthiocholine iodide hydrolyzed $/ \mathrm{min} / \mathrm{g}$ (wet mass) of brain tissue]. Similar results (i.e. no affect) were reported of willets collected near agricultural drainages entering the lower Laguna Madre (Custer and Mitchell 1991).

\section{Conclusions}

We found that most of the tested trace elements, OCs, and HCs were not picked up by redheads on wintering areas in Louisiana and Texas. Concentrations of detected contaminants were usually below reported toxic levels in waterfowl; $\mathrm{B}, \mathrm{Cd}, \mathrm{Cu}, \mathrm{Fe}$, and petroleum hydrocarbons were possible exceptions.

Acknowledgments. D. M. Mackey assisted with the collection and laboratory preparation of specimens. D. A. Fuller provided statistical review and consultation. We are grateful to L. R. Gamble, R. J. Hall, G. H. Heinz, E. F. Hill, B. Mattox, B. A. Rattner, E. J. Rockwell, K. M. St-Pé, B. A. Vairin, and one anonymous reviewer for helpful comments during the review process.

\section{References}

Adair SE (1990) Factors influencing wintering diving duck use of coastal ponds in south Texas. MSc Thesis, Texas A\&M Univ, College Station, TX 
Bellrose FC (1980) Ducks, geese and swans of North America. Stackpole Books, Harrisburg, PA

Benson WW, Brock DW, Gabica J, Loomis M (1976) Swan mortality due to certain heavy metals in the Mission Lake area, Idaho. Bull Environ Contam Toxicol 15:171-174

Boesch DF, Rabalais NN (eds) (1989) Produced waters in sensitive coastal habitats: An analysis of impacts, central coastal Gulf of Mexico. US Dept Int Minerals Manage Serv OCS Rep/MMS 89-0031, Washington, DC

Brealey CJ, Walker CH, Baldwin BC (1980) A-esterase activities in relation to the differential toxicity of pirimiphos-methyl to birds and mammals. Pest Sci 11:546-554

Cornelius SE (1977) Food and resource utilization of wintering redheads on lower Laguna Madre. J Wildl Manage 41:374-385

Cowardin LM, Carter V, Golet FC, LaRoe ET (1979) Classification of wetlands and deepwater habitats of the United States. US Fish Wildl Serv FWS/OBS 79/31

Cromartie EW, Reichel WL, Locke LN, Belisle AA, Kaiser TE, Lamont TG, Mulhern BM, Prouty RM, Swineford DM (1975) Residues of organochlorine pesticides and polychlorinated biphenyls and autopsy data for bald eagles, 1971-72. Pest Monit J 9:11-14

Custer TW, Hohman WL (1993) Trace elements in canvasbacks from Louisiana, 1987-88. Environ Pollut (in press)

Custer TW, Mitchell CA (1987) Exposure to insecticides of brushland wildlife within the Lower Rio Grande Valley, Texas, USA. Environ Pollut 45:207-220

(1991) Contaminant exposure of willets feeding in agricultural drainages of the Lower Rio Grande Valley of South Texas. Environ Monitor Assess 16:189-200

(1993) Trace elements and organochlorines in the shoalgrass community of the lower Laguna Madre, Texas. Environ Monit Assess 25:235-246

Davison KL, Sell JL (1974) Dieldrin and DDT effects on reproduction and some hepatic mixed-function oxidases in the mallard duck. Arch Environ Contam 2(4):302-314

Day RW, Quinn GP (1989) Comparisons of treatments after an analysis of variance in ecology. Ecol Mono 58(4):433-463

Demas CR (1983) Hydrology, water quality, and biology of Baptiste Collette Bayou in relation to the lower Mississippi River at Venice, Louisiana. US Geol Surv Tech Rep No 31

DiGiulio RT (1982) The occurrence and toxicology of heavy metals in Chesapeake Bay waterfowl. PhD Thesis, Virginia Polytech Inst State Univ, Blacksburg, VA

DiGiulio RT, Scanlon PF (1984) Heavy metals in tissues of waterfowl from the Chesapeake Bay, USA. Environ Pollut 35:29-48

Eisler R (1988) Arsenic hazards to fish, wildlife, and invertebrates: A synoptic review. US Fish Wildl Serv Biol Rep 85(1.12)

Elliot JE, Scheuhammer AM, Leighton FA, Pearce PA (1992) Heavy metal and metallothionein concentrations in Atlantic Canadian seabirds. Arch Environ Contam Toxicol 22:63-73

Ellman GL, Courtney KD, Andres Jr V, Featherstone MR (1961) A new and rapid calorimetric determination of acetylcholinesterase activity. Biochem Pharmacol 7:88-98

Fleming WJ, O'Shea TJ (1980) Influence of a local source of DDT pollution on statewide DDT residues in waterfowl wings, northern Alabama, 1978-79. Pest Monit J 14:86-89

Ford WM, Hill EP (1990) Organochlorine contaminants in eggs and tissue of wood ducks from Mississippi. Bull Environ Contam Toxicol 45:870-875

Friend M (1985) Interpretation of criteria commonly used to determine lead poisoning problem areas. US Fish Wildl Serv, Fish Wildl Leafl 2

Gilbert RO (1987) Statistical methods for environmental pollution monitoring. Van Nostrand Reinhold Company, NY

Haegele MA, Hudson RH (1974) Eggshell thinning and residues in mallards one year after DDE exposure. Arch Environ Contam Toxicol 2:356-363
Hall RJ, Coon NC (1988) Interpreting residues of petroleum hydrocarbons in wildlife tissues. US Fish Wildl Serv Bio Rep 88(15)

Hill EF (1988) Brain cholinesterase activity of apparently normal wild birds. J Wildl Dis 24:51-61

(1989) Divergent effects of postmortem ambient temperature on organophosphorus- and carbamate-inhibited brain cholinesterase activity in birds. Pest Biochem Physiol 33:264-275

(1992) Avian toxicology of anticholinesterases. In: Ballantyne B and Marrs TC (eds) Clinical and experimental toxicology of organophosphates and carbamates. Butterworth-Heinemann Ltd, Oxford, pp 272-294

Hill EF, Fleming WJ (1982) Anticholinesterase poisoning of birds: Field monitoring and diagnosis of acute poisoning. Environ Toxicol Chem 1:27-38

Hill EF, Murray HC (1987) Seasonal variation in diagnostic enzymes and biochemical constituents of captive northern bobwhites and passerines. Comp Biochem Physiol 87B:933-940

Hoffman DJ, Heinz GH (1988) Embryotoxic and teratogenic effects of selenium in the diets of mallards. J Toxicol Environ Health $24: 477-490$

Hoffman DJ, Camardese MB, Lecaptain LJ, Pendleton GW (1990) Effects of boron on growth and physiology in mallard ducklings. Environ Toxicol Chem 9:335-346

Irby HD, Locke LN, Bagley GE (1967) Relative toxicity of lead and selected substitute shot types to game farm mallards. J Wildl Manage 31:253-257

Kaiser TE, Reichel WL, Locke LN, Cromartie E, Krynitsky AJ, Lamont TG, Mulhern BM, Prouty RM, Stafford CJ, Swineford DM (1980) Organochlorine pesticides, PCB, and PBB residues and necropsy data for bald eagles from 29 states-1975-77. Pest Monit J 13:145-149

King KA, Stafford CJ, Cain BW, Mueller AJ, Hall HD (1987) Industrial, agricultural, and petroleum contaminants in cormorants wintering near the Houston ship channel, Texas, USA. Colonial Waterbirds 10(1):93-99

Lande E (1977) Heavy metal pollution in Trondheimsfjorden, Norway, and recorded effects on the fauna and flora. Environ Pollut 12:187-198

Lawler, GC, Loong W, Laseter JL (1978) Accumulation of saturated hydrocarbons in tissues of petroleum-exposed mallard ducks (Anas platyrhynchos). Environ Sci Technol 12:47-51

Locke LN, Irby HD, Bagley GE (1967) Histopathology of mallards dosed with lead and selected substitute shot. Bull Wildl Dis Assoc 3:143-147

Longcore JR, Stendell RC (1977) Shell thinning and reproductive impairment in black ducks after cessation of DDE dosage. Arch Environ Contam Toxicol 6:293-304

Lowenstine LJ, Petrak ML (1980) Iron pigment in the livers of birds. In: Montali RJ, Migaki G (eds) The comparative pathology of zoo animals. Smithsonian Institution Press, Washington, DC

Ludke JL, Hill EF, Dieter MP (1975) Cholinesterase (ChE) response and related mortality among birds fed $\mathrm{ChE}$ inhibitors. Arch Environ Contam Toxicol 3:1-21

McMahan CA (1970) Food habits of ducks wintering on Laguna Madre, Texas. J Wildl Manage 34:946-949

Michot TC, Nault AJ (1993) Diet differences in redheads from nearshore and offshore zones in Louisiana. J Wildl Manage 57:238-244

Michot TC, Moser EB, Norling W (1994) Effects of weather and tides on feeding and flock positions of wintering redheads in Chandeleur Sound, Louisiana. Hydrobiologia (in press)

Mitchell, CA (1992) Water depth predicts redhead distribution in the lower Laguna Madre, Texas. Wildl Soc Bull 20:420-424

Mitchell CA, Custer TW, and Zwank PJ (1992) Redhead duck behavior on Lower Laguna Madre and adjacent ponds of southern Texas. Southwest Nat 37:65-72

Moore JL (1991) Habitat-related activities and body mass of wintering redhead ducks on coastal ponds in South Texas. MSc Thesis, Texas A\&M Univ, College Station, TX 
Mora MA, Anderson DW, Mount ME (1987) Seasonal variation of body condition and organochlorines in wild ducks from California and Mexico. J Wildl Manage 51:132-141

Ohlendorf HM (1989) Bioaccumulation and effects of selenium in wildlife. In: Jacobs LW (ed) Selenium in agriculture and the environment. SSSA Spec Pub No 23, Am Soc of Agronomy and Soil Sci, Madison, WI

Ohlendorf HM, Miller MR (1984) Organochlorine contaminants in California waterfowl. J Wildl Manage 48:867-877

Ohlendorf HM, Lowe RW, Kelly PR, Harvey TE (1986) Selenium and heavy metals in San Francisco Bay diving ducks. J Wildl Manage 50:64-71

Pacheco PA, Farrow DRG, Manuelides T, Rohmann SO, Katz M, McLeod J (1990) Point source discharges in coastal areas of Texas: a summary by estuarine watershed for 1987. Draft Report. US Dept Comm, Nat Oceanic Atmos Admn, Rockville, MD

Paasivirta J (1991) Chemical ecotoxicology. Lewis Publishers, Chelsea, MI

Paveglio FL, Bunck CM, Heinz GH (1992) Selenium and boron in aquatic birds from central California. J Wildl Manage 56(1):31-42

Rattner BA, Flickinger EL, Hoffman DJ (1993) Morphological, biochemical, and histopathological indices and contaminant burdens of cotton rats (Sigmodon hispidus) at three hazardous waste sites near Houston, Texas, USA. Environ Pollut 79:85-93

Rhodes RC (1981) Much ado about next to nothing, or what to do with measurements below the detection limit. Environmetrics 81: selected papers, SIAM-SIMS conference series no.8. Society for industrial and applied mathematics, Philadelphia, pp 157-162

Risebrough RW, Anderson DW (1975) Some effects of DDE and PCB on mallards and their eggs. J Wildl Manage 39:508-513

Sabourin TD, Stickle WB, Michot TC, Villars CE, Garton DW, Mushinsky HR (1984) Organochlorine residue levels in Mississippi River water snakes in southern Louisiana. Bull Environ Contam Toxicol 32:460-468
St. Pé KM (ed) (1990) An assessment of produced water impacts to low-energy, brackish water systems in Southeast Louisiana. Louisiana Dept Environ Qual, Water Pollut Control Div, Baton Rouge, LA

SAS Institute Inc (1987) SAS/STAT guide for personal computers, version 6 ed. SAS Inst Inc, Cary, NC

Scheuhammer AM (1987) The chronic toxicity of aluminum, cadmium, mercury, and lead in birds: A review. Environ Pollut 46:263-295

Scott ML, Nesheim MC, Young RJ (1976) Nutrition of the chicken. ML Scott \& Assoc, Ithaca, NY

Shumway RH, Azari AS, Johnson P (1989) Estimating mean concentrations under transformation for environmental data with detection limits. Technometrics 31(3):347-356

Smith GJ, Anders VP (1989) Toxic effects of boron on mallard reproduction. Environ Toxicol Chem 8:943-950

Smith VE, Spurr JM, Filkins JC, Jones JJ (1985) Organochlorine contaminants of wintering ducks foraging on Detroit river sediments. J Great Lakes Res 11:231-246

Vermeer K, Castilla JC (1991) High cadmium residues observed during a pilot study in shorebirds and their prey downstream from $\mathrm{El}$ Salvador copper mine, Chile. Bull Environ Contam Toxicol $46: 242-248$

Walker CH, El Zorgani GA (1974) The comparative metabolism and excretion of HCE, a biodegradable analogue of dieldrin, by vertebrate species. Arch Environ Contam Toxicol 2:97-116

Westlake GE, Martin AD, Stanley PI, Walker CH (1983) Control enzyme levels in the plasma, brain, and liver from wild birds and mammals in Britain. Comp Biochem Physiol 76C:15-24

White DH, Stendell RC, Mulhern BM (1979) Relations of wintering canvasbacks to environmental pollutants-Chesapeake Bay, Maryland. Wilson Bull 91:279-287

Woodin MC (1994) Use of saltwater and freshwater habitats by wintering redheads in southern Texas. Hydrobiologia (in press) 